\title{
Family history of cancer in children and adolescents with germ cell tumours: a report from the Children's Oncology Group
}

Jenny N Poynter ${ }^{*}, 1,2$, Michaela Richardson ${ }^{1}$, Michelle Roesler ${ }^{1}$, Mark Krailo ${ }^{3}$, James F Amatruda ${ }^{4}$ and A Lindsay Frazier ${ }^{5}$

${ }^{1}$ Division of Epidemiology \& Clinical Research, Department of Pediatrics, University of Minnesota, Minneapolis, MN 55455, USA; ${ }^{2}$ Masonic Cancer Center, University of Minnesota, Minneapolis, MN 55455, USA; ${ }^{3}$ Department of Preventive Medicine, University of Southern California, Los Angeles, CA 91016, USA; ${ }^{4}$ Department of Pediatrics, University of Texas Southwestern Medical Center, Dallas, TX 75390, USA and ${ }^{5}$ Dana-Farber/ Boston Children's Cancer and Blood Disorders Center, Boston, MA 02115, USA

Background: Studies of family history of cancer in paediatric germ cell tumours (GCTs) are few, and none has had sufficient sample size to specifically evaluate family history of GCT.

Methods: We utilised family history data from a paediatric GCT study to calculate standardised incidence ratios (SIR) for GCT and other cancers using age- and sex-specific incidence rates from the SEER Program.

Results: This analysis included 7998 relatives of paediatric GCT probands. We observed a higher number of GCT cases than expected in male and female relatives of probands $(\mathrm{SIR}=2.38,95 \% \mathrm{Cl} 1.25,3.51$ for males; $\mathrm{SIR}=14.3,95 \% \mathrm{Cl} 0.29,28.4$ for females). Further, we observed a particularly strong SIR for relatives of probands with intracranial GCT (SIR $=8.07,95 \% \mathrm{Cl} 3.51$, 12.6). The SIR for relatives of probands with ovarian GCT was also elevated but did not reach statistical significance (SIR $4.35,95 \%$ $\mathrm{Cl}$ 0-9.27). Other notable associations include elevated SIRs for melanoma in male relatives and reduced SIRs for lymphatic/ haematologic malignancies in male and female relatives.

Conclusions: These results support the hypothesis that familial aggregation of GCT occurs in males and females.

Family history is one of the few well-established risk factors for adult testicular germ cell tumour (TGCT) (Heimdal et al, 1996; Westergaard et al, 1996; Kharazmi et al, 2015; Litchfield et al, 2015). Among cancers, TGCT has one of the highest reported heritability estimates (Czene et al, 2002; Sampson et al, 2015), although a positive family history represents only $1-3 \%$ of all cases (Dieckmann and Pichlmeier, 1997).

The evidence for a heritable component of ovarian GCT (OGCT) is less conclusive. A study of 74 cases of ovarian GCT found none with a family history (Shulman et al, 1994) while other reports have described families with cases of both ovarian GCT and either TGCT or extragonadal GCT (Giambartolomei et al, 2009).
Population-based studies of familial aggregation do not exist due to the rarity of the disease.

Similarly, there are few studies on family history of cancer in paediatric GCTs, and none with a sufficient sample size to specifically evaluate family history of GCT (Johnston et al, 1986; Walker et al, 1988; Shu et al, 1995; Poynter et al, 2010). In our previous analysis in an independent set of 274 GCT cases, relatives of male cases but not female cases had higher risk of melanoma $(\mathrm{OR}=4.65,9 \%$ CI $1.40-15.4$ for males; $\mathrm{OR}=1.30,95 \%$ CI 0.55 , 3.08 for females; Poynter et al, 2010).

In this analysis, we estimated risk of GCT and other cancers in relatives of paediatric GCT cases. Owing to our relatively large

*Correspondence: Dr JN Poynter; E-mail: poynt006@umn.edu

Received 3 April 2017; revised 14 September 2017; accepted 18 September 2017; published online 24 October 2017

(C) 2018 Cancer Research UK. All rights reserved 0007-0920/18 
sample size of paediatric GCTs, we were able to evaluate associations for GCT overall and stratified by characteristics of the proband.

\section{MATERIALS AND METHODS}

Study participants. Children diagnosed with GCT were identified through the Children's Oncology Group Childhood Cancer Research Network (CCRN) (Musselman et al, 2014) and invited to participate in this case-parent triad study. The CCRN was established by the COG in 2008 to provide a centralised paediatric cancer registry in the United States to facilitate aetiologic and survivorship studies. Children were eligible for the study if they had a primary diagnosis of GCT including germinoma (ICCC code (Steliarova-Foucher et al, 2005) 9060-9065), teratoma (9080-9084), embryonal carcinoma (9070-9072), yolk sac tumour (9071), choriocarcinoma $(9100,9103,9104)$, and mixed GCT (9085, 9101, 9102, 9105) between 1 July 2008 and 31 December 2015. Additional eligibility criteria included age $<20$ years at diagnosis, the availability of at least one biological parent alive and willing to participate, and ability to complete a questionnaire in English or Spanish. Pathology reports were provided by the participating Children's Oncology Group institutions per the CCRN protocol.

All study procedures were approved by the University of Minnesota Institutional Review Board. Parents provided written informed consent prior to completion of questionnaires. GCT probands aged 18 years and older provided informed consent for participation in the study. Assent was obtained from children aged 8-17 years.

Table 1. Demographic and clinical characteristics of the germ cell tumour probands

\begin{tabular}{|c|c|c|}
\hline & $\begin{array}{l}\text { Male probands } \\
\qquad N^{\mathrm{a}}=340\end{array}$ & $\begin{array}{c}\text { Female Probands } \\
\qquad N^{\mathrm{a}}=330\end{array}$ \\
\hline \multicolumn{3}{|l|}{ Age at diagnosis } \\
\hline $0-4$ & $66(19)$ & $105(32)$ \\
\hline $5-9$ & $17(5)$ & 50 (15) \\
\hline $10-14$ & $77(23)$ & $114(35)$ \\
\hline $15-19$ & $180(53)$ & $61(19)$ \\
\hline \multicolumn{3}{|c|}{ Tumour Histology } \\
\hline Germinoma & $103(30)$ & $67(20)$ \\
\hline Teratoma & $51(15)$ & $105(32)$ \\
\hline $\begin{array}{l}\text { Yolk Sac Tumour } \\
\text { (YST) }\end{array}$ & $42(12)$ & $73(22)$ \\
\hline Mixed/Other & $126(37)$ & $50(15)$ \\
\hline Teratoma and YST & $6(2)$ & $27(8)$ \\
\hline Unknown & $12(4)$ & $8(2)$ \\
\hline \multicolumn{3}{|l|}{ Tumour location } \\
\hline Ovary & - & $177(54)$ \\
\hline Testis & $136(40)$ & - \\
\hline Intracranial & $133(39)$ & $52(16)$ \\
\hline Extragonadal & $71(21)$ & $101(31)$ \\
\hline \multicolumn{3}{|l|}{ Cryptorchidism } \\
\hline Yes & $16(5)$ & N/A \\
\hline \multicolumn{3}{|c|}{ Number relatives per family } \\
\hline Mean \# (SD) & $12.5(4.5)$ & $11.4(3.9)$ \\
\hline \multicolumn{3}{|l|}{ Relatives by type } \\
\hline Mothers & 336 & 326 \\
\hline Fathers & 322 & 303 \\
\hline Siblings ${ }^{\mathbf{b}}$ & 591 & 585 \\
\hline Grandparents & 1241 & 1196 \\
\hline Aunts/uncles ${ }^{c}$ & 1754 & 1344 \\
\hline \multicolumn{3}{|c|}{$\begin{array}{l}\mathrm{a}_{\text {a }} \text { Numbers may not sum to total due to missing values. } \\
b_{\text {Includes full and half siblings. }} \\
{ }^{c} \text { Does not include half-aunts and half-uncles. }\end{array}$} \\
\hline
\end{tabular}

Questionnaire data. Mothers and fathers of probands were asked to complete a brief mailed questionnaire including questions about health history, demographics and environmental exposures. We collected a complete family cancer history from both mothers and fathers, including information on parents, siblings, grandparents, and aunts/uncles of the proband. We also asked about history of benign conditions of the reproductive organs in relatives, with a focus on ovarian cysts and cryptorchidism.

Calculation of standardised incidence ratios (SIR). We calculated SIR to determine excess risk of GCT and other cancers in relatives of probands by comparing the ratio of observed number of cases to expected number of cases. The expected number of cases was determined by using age- and sex-specific incidence rates from the NCI's SEER Program. Cancer sites were grouped into categories based on ICD-9-CM groupings: (1) lip, oral cavity, and pharynx; (2) oesophagus, stomach, and small intestine; (3) colon and rectum; (4) liver, gallbladder, and pancreas; (5) lung; (6) melanoma; (7) breast; (8) uterus, ovary; (9) prostate; (11) bladder and kidney; (12) lymphatic, haematologic. GCTs in SEER were identified using ICD-O-3 histology codes (9060-9065, 9070-9072, 9080-9085, 9100-9105). Person-years were calculated from the date of birth to the first date of the following: cancer diagnosis, interview or death. We calculated SIRs stratified by sex of the relatives. For GCT, we also stratified analyses by characteristics of the proband, including sex, age at diagnosis, tumour location and tumour histology. Because we have a priori evidence for an association between paediatric GCT and family history of GCT or melanoma, these associations were not corrected for multiple comparisons. For other cancer types, we used a Bonferroni correction to account for the number of cancers we evaluated $(P<0.004$ for 10 tests). SIR and 95\% confidence intervals $(\mathrm{CI})$ were computed using indirect standardisation in SAS v9.4 (Cary, NC, USA).

\section{RESULTS}

Family history data were available for 670 GCT probands (Table 1). Age at diagnosis differed by sex of the proband, with more male cases than female cases diagnosed after age 10 years (76 vs 54\%). Differences were also observed by tumour location and histology. Parents of male and female probands reported cancer history for 12 family members on average (Table 1).

The number of observed cases of GCT was higher than the expected number of cases in both male and female relatives $(\mathrm{SIR}=2.38,95 \%$ CI $1.25,3.51 ; \mathrm{SIR}=14.3,95 \%$ CI $0.29,28.41$, respectively), although the SIR in female relatives had wide confidence limits and did not reach statistical significance (Table 2). In male relatives, we also observed a statistically significantly higher number of melanomas (SIR $=1.78,95 \% \mathrm{CI}$ $1.20,2.36)$ than expected. A lower than expected number of lymphatic/haematologic cancers was observed in both male and female relatives (Table 2 ).

We observed a higher than expected number of GCTs in relatives of both male and female probands. In males, we were only able to quantify the excess number of cancers in relatives of probands diagnosed at age 11 years or older ( SIR $=4.05,95 \% \mathrm{CI}$ $1.54,6.56)$ due to small numbers of probands $<11$. An excess number of cases were reported in relatives of girls diagnosed at any age, although the SIRs did not reach statistical significance (Table 3). SIRs were significantly elevated for relatives of probands with germinoma (Table 3). More than half of the affected relatives were from a family where the proband had an intracranial GCT. Pedigrees for the 21 families with a history of GCT are included in the Supplementary Information. No family had more than two 
Table 2. Standardised incidence ratios for cancer by subtype in male and female relatives of GCT probands

\begin{tabular}{|c|c|c|c|c|c|c|c|c|c|c|}
\hline & $\mathrm{N}_{\text {OBSERVED }}$ & $N_{\text {EXPECTED }}$ & $\mathrm{IR}_{\mathrm{SEER}}$ & $\operatorname{SIR}(95 \% \mathrm{CI})^{\mathrm{b}}$ & $\begin{array}{c}P- \\
\text { value }\end{array}$ & $\mathrm{N}_{\text {OBSERVED }}$ & $\mathrm{N}_{\text {EXPECTED }}$ & $\mathrm{IR}_{\mathrm{SEER}}$ & $\operatorname{SIR}(95 \% \mathrm{CI})^{\mathrm{b}}$ & $P$-value \\
\hline Malignancies & \multicolumn{4}{|c|}{ Male relatives of proband } & \multicolumn{6}{|c|}{ Female relatives of proband } \\
\hline $\begin{array}{l}\text { Oesophageal/ } \\
\text { stomach/small } \\
\text { intestine }\end{array}$ & 13 & 13 & 18.3 & $1.01(0.46-1.55)$ & 0.98 & 2 & 1 & 10.1 & - & 0.64 \\
\hline Lung & 42 & 48 & 61.7 & $0.87(0.60-1.13)$ & 0.32 & 16 & 23 & 50.4 & $0.70(0.36-1.04)$ & 0.09 \\
\hline Melanoma & 36 & 20 & 20.8 & $1.78(1.20-2.36)$ & 0.009 & 26 & 18 & 15.3 & $1.48(0.91-2.04)$ & 0.10 \\
\hline Breast & 2 & 0 & 1.0 & - & 0.23 & 139 & 141 & 133.2 & $0.98(0.82-1.15)$ & 0.85 \\
\hline Uterine/ovarian & - & - & & & & 75 & 68 & 48.8 & $1.10(0.85-1.35)$ & 0.44 \\
\hline Bladder/kidney & 29 & 26 & 44.6 & $1.12(0.71-1.53)$ & 0.57 & 2 & 4 & 18.6 & - & 0.28 \\
\hline $\begin{array}{l}\text { Lymphatic/ } \\
\text { haematologic }\end{array}$ & 29 & 48 & 45.2 & $0.60(0.38-0.82)$ & 0.003 & 20 & 43 & 35.2 & $\begin{array}{l}0.46(0.26- \\
0.66)\end{array}$ & $<0.001$ \\
\hline \multicolumn{11}{|c|}{ 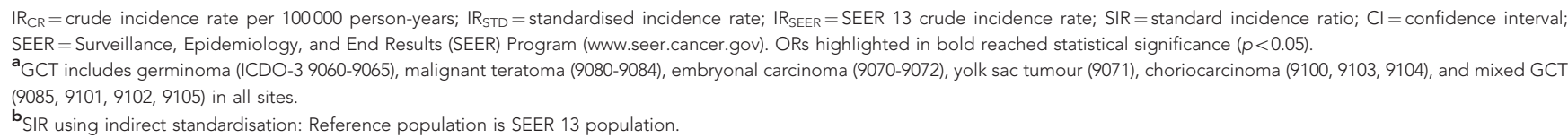 } \\
\hline
\end{tabular}

individuals with GCT. Tumour location was the same in the proband and the affected relative in $9 / 21$ families (43\%).

\section{DISCUSSION}

In this population-based study, we were able to evaluate family history of GCT and other cancers in relatives of paediatric GCT probands. Male and female relatives of probands had a higher number of GCTs than expected when compared with incidence data from the NCI's SEER programme, although this reached statistical significance only among male relatives. This increase in reported GCTs was observed in relatives of both male and female probands. Notably, the majority of reported GCTs occurred in relatives of probands with an intracranial tumour (IGCT).

Family history has not been evaluated extensively in OGCT. Case reports of families with affected male and female relatives and also several studies reporting multiple affected female cases in the same family have been described in the literature (reviewed in Giambartolomei et al, 2009). The three GCTs reported relatives of OGCT cases in our study is higher than the expected number based on SEER incidence rates; however, the confidence intervals for our SIR calculation were very wide given the limited number of probands. This underscores the need for additional studies to confirm our findings; however, our analysis does provide the first quantitative information regarding this association.

Studies of family history of cancer in children with malignant GCTs are limited in number, with only four previous studies reporting associations between family history of cancer and paediatric GCT (Johnston et al, 1986; Walker et al, 1988; Shu et al, 1995; Poynter et al, 2010). No clear associations between risk of GCT and family history of cancer emerged. The lack of previous associations for prostate cancer and lymphatic/haematologic malignancy suggests that these findings should be considered hypothesis-generating and provide future avenues for research. In contrast, previous studies have provided some evidence for a relationship with family history of melanoma and adult testicular cancer (Hemminki and Chen, 2006; Larson et al, 2007; Serrano et al, 2016). In support of our previous findings suggesting an elevated risk of melanoma in relatives of paediatric GCT cases (Poynter et al, 2010), we observed an elevated risk of melanoma in male relatives of probands and an elevated, but non-significant risk of melanoma in female relatives of probands. Hormones have been hypothesised to play a role in both melanoma and GCT (Henderson et al, 1979; Walker et al, 1988; Mitkov et al, 2015) and could potentially explain this relationship. KITLG, the genetic locus with the strongest per allele association in testicular GCT (Wang et al, 2017), plays a role in determining pigmentation (Miller et al, 2007), suggesting another potentially shared aetiologic factor.

None of the previous studies of family history in paediatric GCT has had power to specifically evaluate the relationship with family history of GCT. In the current analysis, we were able to evaluate risk of GCT specifically in relatives of male and female GCT cases. GCTs in adolescent males exhibit molecular and clinical features that more closely resemble adult TGCT than prepubertal GCT; thus, it is not surprising that we observed familial aggregation in relatives of these cases. The majority of reported GCTs occurred in male relatives (17/21); however, we did also observe a higher than expected number of GCTs in female relatives. Three of the four female relatives with GCT were related to a female proband. No family in the study had more than two affected individuals. In this respect, the association with family history in paediatric GCT is very similar to what is known about family history in adult testicular GCT, where the majority of families have two affected cases (Mai et al, 2010).

A majority of the reported GCTs this study occurred in relatives of a proband with an intracranial tumour. Little is known about the aetiology of IGCT; however, genetic aetiology is likely given international incidence patterns (Poynter et al, 2014) and is supported by recent publications identifying JMJDC1 as a susceptibility locus (Wang et al, 2014). Family history has not 
Table 3. Standardised incidence ratios for $\mathrm{GCT}^{\mathrm{a}}$ in relatives by proband characteristics

\begin{tabular}{|c|c|c|c|}
\hline $\begin{array}{l}\text { Characteristic of } \\
\text { proband }\end{array}$ & NobSERVED & $\mathbf{N}_{\text {EXPECTED }}$ & $\operatorname{SIR}(95 \% \mathrm{CI})^{\mathrm{b}}$ \\
\hline \multicolumn{4}{|l|}{ Sex } \\
\hline Males & 11 & 3.2 & $3.47(1.42-5.52)$ \\
\hline Females & 10 & 2.5 & $3.94(1.50-6.38)$ \\
\hline \multicolumn{4}{|l|}{ Age at diagnosis } \\
\hline$<11$ & 6 & 1.3 & $4.63(0.93-8.34)$ \\
\hline$\geqslant 11$ & 15 & 5.2 & $2.89(1.43-4.35)$ \\
\hline \multicolumn{4}{|l|}{ Sex and age } \\
\hline Males $<11$ & 1 & 0.1 & - \\
\hline Males $\geqslant 11$ & 10 & 2.5 & $4.05(1.54-6.56)$ \\
\hline Females $<11$ & 5 & 0.8 & $6.11(0.75-11.5)$ \\
\hline Females $\geqslant 11$ & 5 & 1 & $5.16(0.64-9.68)$ \\
\hline \multicolumn{4}{|l|}{ Race } \\
\hline Non-Hispanic, white & 19 & 4.5 & $4.26(2.34-6.17)$ \\
\hline Other & 2 & 0.6 & $3.00(0-7.17)$ \\
\hline \multicolumn{4}{|l|}{ Tumour histologyc } \\
\hline Germinoma & 10 & 1.4 & 7.15 (2.72-11.59) \\
\hline Teratoma & 4 & 0.8 & $4.76(0.10-9.42)$ \\
\hline Yolk sac tumour & 2 & 0.4 & $5.45(0-13.1)$ \\
\hline Mixed/other & 4 & 0.4 & $9.14(0.18-18.10)$ \\
\hline \multicolumn{4}{|l|}{ Tumour location } \\
\hline Intracranial & 12 & 1.5 & 8.07 (3.51-12.6) \\
\hline $\begin{array}{l}\text { Extracranial and } \\
\text { extragonadal }\end{array}$ & 2 & 0.5 & $3.78(0-9.03)$ \\
\hline Testis & 4 & 0.4 & $11.15(0.22-22.08)$ \\
\hline Ovary & 3 & 0.7 & $4.35(0-9.27)$ \\
\hline \multicolumn{4}{|c|}{ 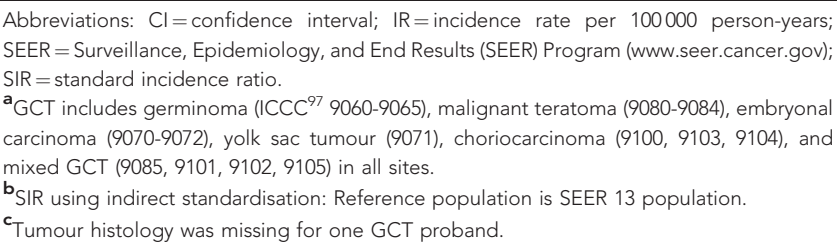 } \\
\hline
\end{tabular}

been evaluated systematically as a risk factor for IGCT, although several case reports of familial IGCT have been published (Nakasu et al, 1983; Kido et al, 1984; Aoyama et al, 1994; Shimizu et al, 2014). These data suggest that family history is likely to be important and should be evaluated further in additional studies. If confirmed, these findings could have clinical implications as the diagnosis of intracranial GCT may prompt evaluation of GCT in other family members.

There are several strengths associated with this study, including the large number of cases assembled for this rare paediatric cancer and the inclusion of GCTs at all locations in males and females in the paediatric and adolescent age groups. There are also several limitations that must be taken into account. The most serious limitation is the reliance on self-report of cancer diagnoses. Validation data suggest that reporting is accurate for common cancers (Kerber and Slattery, 1997; Airewele et al, 1998; Ziogas and Anton-Culver, 2003; Murff et al, 2004); however, at least one report has identified lower accuracy for reporting of testicular cancer (Pinsky et al, 2003). We did not obtain medical records to validate any reported cancer diagnoses; however, we did contact families with a reported history of GCT to obtain additional information on tumour location and age at diagnosis. As expected, report of cancer history in first-degree relatives is typically more accurate compared with reports for more distant relatives (Airewele et al, 1998; Ziogas and Anton-Culver, 2003; Murff et al, 2004; Mai et al, 2011). Although we evaluated associations between both first (parents) and second (grandparents and aunts/ uncles) degree relatives of the probands, it is important to note that the parents provided family history information about their first-degree relatives. We might then expect the information about children's second-degree relatives to be more accurate than in comparable studies of adult cancers. The young age of the relatives in our study population is also a limitation, as most have not reached the peak age for risk of cancer.

Other limitations include the low participation rate among eligible GCT cases based on CCRN data (56\%); however, the distribution of demographic and tumour characteristics is similar in the participating and non-participating cases. In addition, our previous analyses demonstrate that the CCRN includes only a subset of the GCT cases diagnosed in the United States (Musselman et al, 2014). The eligible cases in the CCRN were more likely to be female, younger at diagnosis, more likely to have YST, and less likely to have a testicular tumour when compared with the distribution of cases in SEER (data not shown). This is not surprising given the knowledge that adolescent patients with TGCT are often treated by adult oncologists (Olson et al, 2015). If non-participating COG cases or GCT cases treated at a non-COG institution differ with respect to family history of GCT, it is possible that our findings may be biased.

In conclusion, we report higher than expected numbers of GCTs in relatives of probands enrolled in our series of GCT cases recruited through the Childhood Cancer Research Network. These results were observed in both males and females and in tumours of differing tumour location and histologic subtypes, suggesting that the familial aggregation of GCT is not restricted to adult TGCT. This familial aggregation suggests that paediatric GCT may also have genetic aetiology that should be evaluated in future studies.

\section{ACKNOWLEDGEMENTS}

This work was supported by the National Institutes of Health (R01 CA151284, U10CA180886, U10CA180899) and the Children's Cancer Research Fund, Minneapolis, MN, USA.

\section{CONFLICT OF INTEREST}

The authors declare no conflict of interest.

\section{REFERENCES}

Airewele G, Adatto P, Cunningham J, Mastromarino C, Spencer C, Sharp M, Sigurdson A, Bondy M (1998) Family history of cancer in patients with glioma: a validation study of accuracy. J Natl Cancer Inst 90(7): 543-544. Aoyama I, Kondo A, Ogawa H, Ikai Y (1994) Germinoma in siblings: case reports. Surg neurol 41(4): 313-317.

Czene K, Lichtenstein P, Hemminki K (2002) Environmental and heritable causes of cancer among 9.6 million individuals in the Swedish FamilyCancer Database. Int J Cancer 99(2): 260-266.

Dieckmann KP, Pichlmeier U (1997) The prevalence of familial testicular cancer: an analysis of two patient populations and a review of the literature. Cancer 80(10): 1954-1960.

Giambartolomei C, Mueller CM, Greene MH, Korde LA (2009) A mini-review of familial ovarian germ cell tumors: an additional manifestation of the familial testicular germ cell tumor syndrome. Cancer Epidemiol 33(1): 31-36.

Heimdal K, Olsson H, Tretli S, Flodgren P, Borresen AL, Fossa SD (1996) Familial testicular cancer in Norway and southern Sweden. Br J Cancer 73(7): 964-969.

Hemminki K, Chen B (2006) Familial risks in testicular cancer as aetiological clues. Int J Androl 29(1): 205-210.

Henderson BE, Benton B, Jing J, Yu MC, Pike MC (1979) Risk factors for cancer of the testis in young men. Int J Cancer 23(5): 598-602.

Johnston HE, Mann JR, Williams J, Waterhouse JA, Birch JM, Cartwright RA, Draper GJ, Hartley AL, McKinney PA, Hopton PA (1986) The InterRegional, Epidemiological Study of Childhood Cancer (IRESCC): 
casecontrol study in children with germ cell tumours. Carcinogenesis 7(5): 717-722.

Kerber RA, Slattery ML (1997) Comparison of self-reported and databaselinked family history of cancer data in a case-control study. Am J Epidemiol 146(3): 244-248.

Kharazmi E, Hemminki K, Pukkala E, Sundquist K, Tryggvadottir L, Tretli S, Olsen JH, Fallah M (2015) Cancer risk in relatives of testicular cancer patients by histology type and age at diagnosis: a joint study from five nordic countries. Eur Urol 68(2): 283-289.

Kido G, Takeuchi T, Tsukiyama T, Nakamura S, Tsubokawa T, Henmi A (1984) Tumor of the pineal region in three brothers. No shinkei geka Neurol surg 12(8): 975-980.

Larson AA, Leachman SA, Eliason MJ, Cannon-Albright LA (2007) Population-based assessment of non-melanoma cancer risk in relatives of cutaneous melanoma probands. J Invest Dermatol 127(1): 183-188.

Litchfield K, Thomsen H, Mitchell JS, Sundquist J, Houlston RS, Hemminki K, Turnbull C (2015) Quantifying the heritability of testicular germ cell tumour using both population-based and genomic approaches. Sci rep $\mathbf{5}$ : 13889.

Mai PL, Friedlander M, Tucker K, Phillips KA, Hogg D, Jewett MA, Lohynska R, Daugaard G, Richard S, Bonaiti-Pellie C, Heidenreich A, Albers P, Bodrogi I, Geczi L, Olah E, Daly PA, Guilford P, Fossa SD, Heimdal K, Liubchenko L, Tjulandin SA, Stoll H, Weber W, Easton DF, Dudakia D, Huddart R, Stratton MR, Einhorn L, Korde L, Nathanson KL, Bishop DT, Rapley EA, Greene MH (2010) The International Testicular Cancer Linkage Consortium: a clinicopathologic descriptive analysis of 461 familial malignant testicular germ cell tumor kindred. Urol Oncol 28(5): 492-499.

Mai PL, Garceau AO, Graubard BI, Dunn M, McNeel TS, Gonsalves L, Gail MH, Greene MH, Willis GB, Wideroff L (2011) Confirmation of family cancer history reported in a population-based survey. J Natl Cancer Inst 103(10): 788-797.

Miller CT, Beleza S, Pollen AA, Schluter D, Kittles RA, Shriver MD, Kingsley DM (2007) cis-Regulatory changes in Kit ligand expression and parallel evolution of pigmentation in sticklebacks and humans. Cell 131(6): 1179-1189.

Mitkov M, Joseph R, Copland 3rd J (2015) Steroid hormone influence on melanomagenesis. Mol Cell Endocrinol 417: 94-102.

Murff HJ, Spigel DR, Syngal S (2004) Does this patient have a family history of cancer? An evidence-based analysis of the accuracy of family cancer history. JAMA 292(12): 1480-1489.

Musselman JR, Spector LG, Krailo MD, Reaman GH, Linabery AM, Poynter JN, Stork SK, Adamson PC, Ross JA (2014) The Children's Oncology Group Childhood Cancer Research Network (CCRN): case catchment in the United States. Cancer 120(19): 3007-3015.

Nakasu S, Handa J, Hazama F, Hirakawa K (1983) Suprasellar yolk-sac tumor in two sisters. Surg neurol 20(2): 147-151.

Nitta N, Fukami T, Nozaki K (2013) Germinoma in two brothers: case report. Neurol med-chir 53(10): 703-706.

Olson TA, Murray MJ, Rodriguez-Galindo C, Nicholson JC, Billmire DF, Krailo MD, Dang HM, Amatruda JF, Thornton CM, Arul GS, Stoneham SJ, Pashankar F, Stark D, Shaikh F, Gershenson DM, Covens A, Hurteau J, Stenning SP, Feldman DR, Grimison PS, Huddart RA, Sweeney C, Powles T, Lopes LF, dos Santos Agular S, Chinnaswamy G, Khaleel S, Abouelnaga S, Hale JP, Frazier AL (2015) Pediatric and adolescent extracranial germ cell tumors: the road to collaboration. J Clin Oncol 33(27): 3018-3028.

Pinsky PF, Kramer BS, Reding D, Buys S (2003) Reported family history of cancer in the prostate, lung, colorectal, and ovarian cancer screening trial. Am J Epidemiol 157(9): 792-799.

Poynter JN, Fonstad R, Tolar J, Spector LG, Ross JA (2014) Incidence of intracranial germ cell tumors by race in the United States, 1992-2010. J Neurooncol 120(2): 381-388.

Poynter JN, Radzom AH, Spector LG, Puumala S, Robison LL, Chen Z, Ross JA, Shu XO (2010) Family history of cancer and malignant germ cell tumors in children: a report from the Children's Oncology Group. Cancer Causes Control 21(2): 181-189.

Sampson JN, Wheeler WA, Yeager M, Panagiotou O, Wang Z, Berndt SI, Lan Q, Abnet CC, Amundadottir LT, Figueroa JD, Landi MT, Mirabello L, Savage SA, Taylor PR, De Vivo I, McGlynn KA, Purdue MP, Rajaraman P, Adami HO, Ahlbom A, Albanes D, Amary MF, An SJ, Andersson U, Andriole Jr G, Andrulis IL, Angelucci E, Ansell SM, Arici C, Armstrong BK, Arslan AA, Austin MA, Baris D, Barkauskas DA,
Bassig BA, Becker N, Benavente Y, Benhamou S, Berg C, Van Den Berg D, Bernstein L, Bertrand KA, Birmann BM, Black A, Boeing H, Boffetta P, Boutron-Ruault MC, Bracci PM, Brinton L, Brooks-Wilson AR, Bueno-deMesquita HB, Burdett L, Buring J, Butler MA, Cai Q, Cancel-Tassin G, Canzian F, Carrato A, Carreon T, Carta A, Chan JK, Chang ET, Chang GC, Chang IS, Chang J, Chang-Claude J, Chen CJ, Chen CY, Chen C, Chen CH, Chen C, Chen H, Chen K, Chen KY, Chen KC, Chen Y, Chen YH, Chen YS, Chen YM, Chien LH, Chirlaque MD, Choi JE, Choi YY, Chow WH, Chung CC, Clavel J, Clavel-Chapelon F, Cocco P, Colt JS, Comperat E, Conde L, Connors JM, Conti D, Cortessis VK, Cotterchio M, Cozen W, Crouch S, Crous-Bou M, Cussenot O, Davis FG, Ding T, Diver WR, Dorronsoro M, Dossus L, Duell EJ, Ennas MG, Erickson RL, Feychting M, Flanagan AM, Foretova L, Fraumeni Jr JF, Freedman ND, Beane Freeman LE, Fuchs C, Gago-Dominguez M, Gallinger S, Gao YT, Gapstur SM, Garcia-Closas M, Garcia-Closas R, Gascoyne RD, Gastier-Foster J, Gaudet MM, Gaziano JM, Giffen C, Giles GG, Giovannucci E, Glimelius B, Goggins M, Gokgoz N, Goldstein AM, Gorlick R, Gross M, Grubb 3rd R, Gu J, Guan P, Gunter M, Guo H, Habermann TM, Haiman CA, Halai D, Hallmans G, Hassan M, Hattinger C, He Q, He X, Helzlsouer K, Henderson B, Henriksson R, Hjalgrim H, Hoffman-Bolton J, Hohensee C, Holford TR, Holly EA, Hong YC, Hoover RN, Horn-Ross PL, Hosain GM, Hosgood 3rd HD, Hsiao CF, Hu N, Hu W, Hu Z, Huang MS, Huerta JM, Hung JY, Hutchinson A, Inskip PD, Jackson RD, Jacobs EJ, Jenab M, Jeon HS, Ji BT, Jin G, Jin L, Johansen C, Johnson A, Jung YJ, Kaaks R, Kamineni A, Kane E, Kang CH, Karagas MR, Kelly RS, Khaw KT, Kim C, Kim HN, Kim JH, Kim JS, Kim YH, Kim YT, Kim YC, Kitahara CM, Klein AP, Klein RJ, Kogevinas M, Kohno T, Kolonel LN, Kooperberg C, Kricker A, Krogh V, Kunitoh H, Kurtz RC, Kweon SS, LaCroix A, Lawrence C, Lecanda F, Lee VH, Li D, Li H, Li J, Li YJ, Li Y, Liao LM, Liebow M, Lightfoot T, Lim WY, Lin CC, Lin D, Lindstrom S, Linet MS, Link BK, Liu C, Liu J, Liu L, Ljungberg B, Lloreta J, Di Lollo S, Lu D, Lund E, Malats N, Mannisto S, Le Marchand L, Marina N, Masala G, Mastrangelo G, Matsuo K, Maynadie M, McKay J, McKean-Cowdin R, Melbye M, Melin BS, Michaud DS, Mitsudomi T, Monnereau A, Montalvan R, Moore LE, Mortensen LM, Nieters A, North KE, Novak AJ, Oberg AL, Offit K, Oh IJ, Olson SH, Palli D, Pao W, Park IK, Park JY, Park KH, Patino-Garcia A, Pavanello S, Peeters PH, Perng RP, Peters U, Petersen GM, Picci P, Pike MC, Porru S, Prescott J, Prokunina-Olsson L, Qian B, Qiao YL, Rais M, Riboli E, Riby J, Risch HA, Rizzato C, Rodabough R, Roman E, Roupret M, Ruder AM, Sanjose S, Scelo G, Schned A, Schumacher F, Schwartz K, Schwenn M, Scotlandi K, Seow A, Serra C, Serra M, Sesso HD, Setiawan VW, Severi G, Severson RK, Shanafelt TD, Shen H, Shen W, Shin MH, Shiraishi K, Shu XO, Siddiq A, Sierrasesumaga L, Sihoe AD, Skibola CF, Smith A, Smith MT, Southey MC, Spinelli JJ, Staines A, Stampfer M, Stern MC, Stevens VL, Stolzenberg-Solomon RS, Su J, Su WC, Sund M, Sung JS, Sung SW, Tan W, Tang W, Tardon A, Thomas D, Thompson CA, Tinker LF, Tirabosco R, Tjonneland A, Travis RC, Trichopoulos D, Tsai FY, Tsai YH, Tucker M, Turner J, Vajdic CM, Vermeulen RC, Villano DJ, Vineis P, Virtamo J, Visvanathan K, Wactawski-Wende J, Wang C, Wang CL, Wang JC, Wang J, Wei F, Weiderpass E, Weiner GJ, Weinstein S, Wentzensen N, White E, Witzig TE, Wolpin BM, Wong MP, Wu C, Wu G, Wu J, Wu T, Wu W, Wu X, Wu YL, Wunder JS, Xiang YB, Xu J, Xu P, Yang PC, Yang TY, Ye Y, Yin Z, Yokota J, Yoon HI, Yu CJ, Yu H, Yu K, Yuan JM, Zelenetz A, Zeleniuch-Jacquotte A, Zhang XC, Zhang Y, Zhao X, Zhao Z, Zheng H, Zheng T, Zheng W, Zhou B, Zhu M, Zucca M, Boca SM, Cerhan JR, Ferri GM, Hartge P, Hsiung CA, Magnani C, Miligi L, Morton LM, Smedby KE, Teras LR, Vijai J, Wang SS, Brennan P, Caporaso NE, Hunter DJ, Kraft P, Rothman N, Silverman DT, Slager SL, Chanock SJ, Chatterjee N (2015) Analysis of heritability and shared heritability based on genome-wide association studies for thirteen cancer types. J Natl Cancer Inst 107(12): djv279.

Serrano PF, Serrano JL, Allam MF, Navajas RF (2016) Correlations between cutaneous malignant melanoma and other cancers: an ecological study in forty European countries. Int J Prev Med 7: 73.

Shimizu K, Mineharu Y, Imamura H, Asai K, Imai Y, Ichimura K, Sakai N (2014) Intracranial germinomas in a father and his son. Childs Nerv Syst 30(12): 2143-2146.

Shu XO, Nesbit ME, Buckley JD, Krailo MD, Robinson LL (1995) An exploratory analysis of risk factors for childhood malignant germ-cell tumors: report from the Childrens Cancer Group (Canada, United States). Cancer Causes Control 6(3): 187-198. 
Shulman LP, Muram D, Marina N, Jones C, Portera JC, Wachtel SS, Simpson JL, Elias S (1994) Lack of heritability in ovarian germ cell malignancies. Am J Obstet Gynecol 170(6): 1803-1805discussion 1805-1808.

Steliarova-Foucher E, Stiller C, Lacour B, Kaatsch P (2005) International classification of childhood cancer, third edition. Cancer 103(7): 1457-1467.

Walker AH, Ross RK, Haile RW, Henderson BE (1988) Hormonal factors and risk of ovarian germ cell cancer in young women. Br J Cancer 57(4): 418-422.

Wang L, Yamaguchi S, Burstein MD, Terashima K, Chang K, Ng HK, Nakamura H, He Z, Doddapaneni H, Lewis L, Wang M, Suzuki T, Nishikawa R, Natsume A, Terasaka S, Dauser R, Whitehead W, Adekunle A, Sun J, Qiao Y, Marth G, Muzny DM, Gibbs RA, Leal SM, Wheeler DA, Lau CC (2014) Novel somatic and germline mutations in intracranial germ cell tumours. Nature 511(7508): 241-245.

Wang Z, McGlynn KA, Rajpert-De Meyts E, Bishop DT, Chung CC, Dalgaard MD, Greene MH, Gupta R, Grotmol T, Haugen TB, Karlsson R, Litchfield K, Mitra N, Nielsen K, Pyle LC, Schwartz SM, Thorsson V,
Vardhanabhuti S, Wiklund F, Turnbull C, Chanock SJ, Kanetsky PA, Nathanson KL, Testicular Cancer C (2017) Meta-analysis of five genomewide association studies identifies multiple new loci associated with testicular germ cell tumor. Nat Genet 49(7): 1141-1147.

Westergaard T, Olsen JH, Frisch M, Kroman N, Nielsen JW, Melbye M (1996) Cancer risk in fathers and brothers of testicular cancer patients in Denmark. A population-based study. Int J Cancer 66(5): 627-631.

Ziogas A, Anton-Culver H (2003) Validation of family history data in cancer family registries. Am J Prev Med 24(2): 190-198.

This work is published under the standard license to publish agreement. After 12 months the work will become freely available and the license terms will switch to a Creative Commons AttributionNonCommercial-Share Alike 4.0 Unported License.

Supplementary Information accompanies this paper on British Journal of Cancer website (http://www.nature.com/bjc) 